\title{
SW3 救急医療と表景をなす救急医学大系の確立をめざして
}

\section{SW3-1}

\section{救急医学と救急医療のあるべき姿}

- $\mathrm{EBM}$ から NBMへー

誠友会南部病院脳神経外科

上田 孝

\section{はじめに}

医に関する学問を医学と呼び，医学的治療の実践を医 療と考えれば，救急医学と救急医療の関係は表裏という よりも，むしろ救急医学は救急医療の土台，基盤と言え る。体に起こる病理学的変化を疾患 (disease), それに伴 う患者の主観的な苦しみを病気（illness）と定義される。 医師が病気を理解するには，それをどのように解釈し， 疾患を持つ患者が何を期待し，何を恐れ，どんな感情を 持って，どのような影響を考えているのかを知ることが 必須である。すなわち病気とは，患者を主人公として患 者本人によって語られる物語りとして理解される。どん
なに高度先進医療が普及しても，どんなにEBM，クリニ カルパスが導入されても医師と患者，家族との間の言葉， 対話，物語りが織り成す narrative based medicine（NBM） の重要性が色褪せることはない。ガイドラインに沿った 治療のみでは十分満足のいく結果が得られないのは周知 の事実である。21世紀の救急医は急性期治療をした，集 中管理をした，後はよろしくの時代ではない。広く得ら れた患者の個々の科学的デー夕から, 個人, 個性を大切 にするという理念に基づき，他科治療医のみならず看護 部, リハビリテーション部, 栄養課, 薬剤部等と共同し てチームワーク医療を進めつつ，医師と患者，家族が共 通の情報 (救急医学) を十分に共有し同じ理解基盤に 立って意志決定 (救急医療) していく，すなわちEBMを 包含したNBM が重要と思われる。救急に携わる私達は もっと narrativeになるべきである。具体的な症例を呈示 しながら NBMの重要性を述べたい。

\section{1. 症例呈示}

平成 10 年 $\times$ 月 $\times$ 日, 75 歳の男性が深夜の午前 2 時頃 自宅のトイレに行こうとして立ち上がろうとしたが，右 半身の力が入らなかった。そこで声を出して人を呼ぼう としたが言葉が思うように出なかった。何か物音がした ので隣の部屋にいた妻が夫にかけ寄ると何とか左手を動

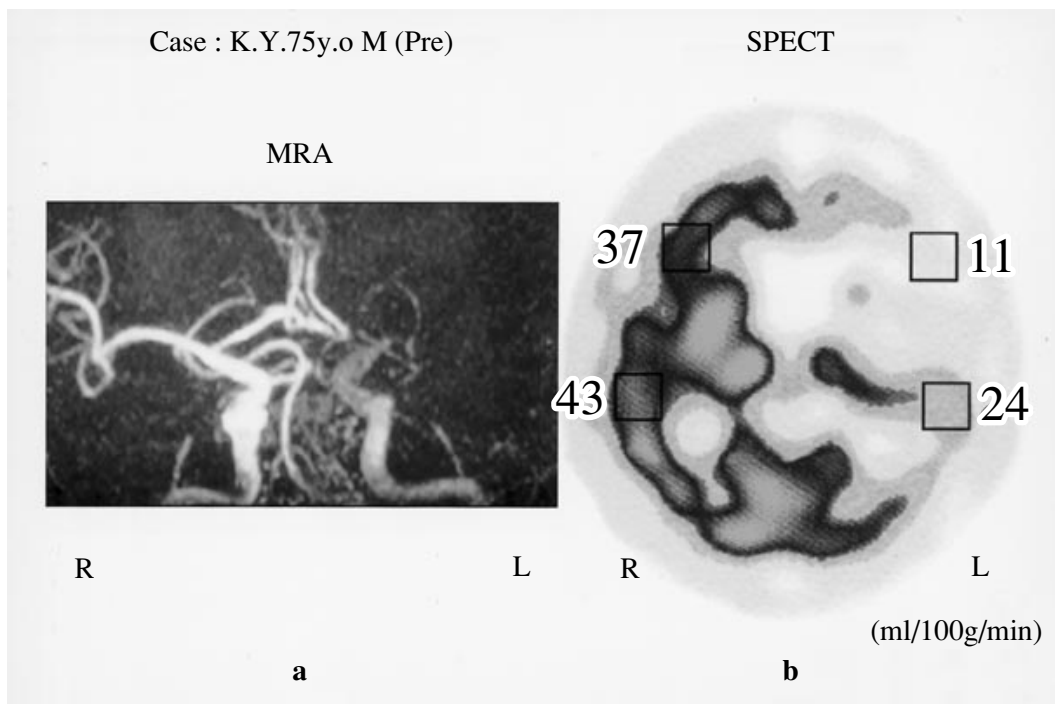

Fig.1. Acute cerebral ischemia.

a: MRA demonstrated obstruction of left top of internal carotid artery (ICA).

b: Markedly decreased of regional cerebral blood flow (rCBF) in the left frontal and parietal lobes. 
Table 1. Acute thrombolytic therapy guideline 2004.

\begin{tabular}{llll}
\hline & & & Grade \\
& & A \\
t-Pa & DIV $<3$ hr & CT $(-)$ & C1 \\
UK & DIV $<5$ days & & B \\
t-Pa & IVR $<6 h r$ & CT $(-)$ & D \\
\hline
\end{tabular}

CT $(-)$ : no change of CT findings

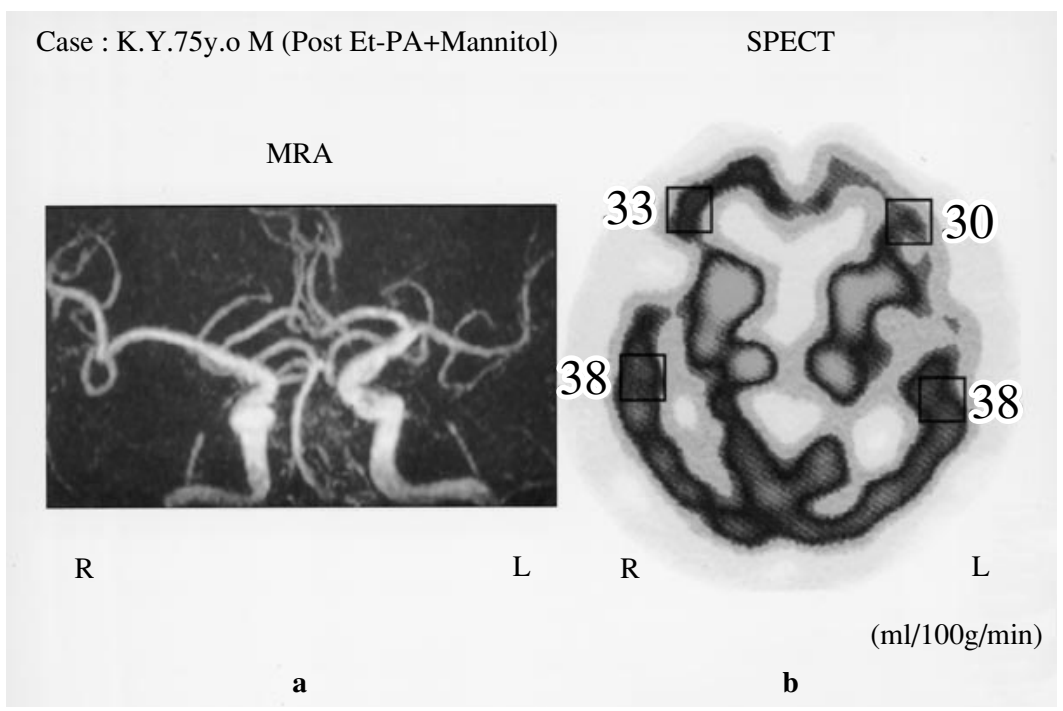

Fig. 2. Same case of Table 1. Post treatment.

a: MRA demonstrated recanalization of left ICA after intravenous injection therapy of Et-PA and mannitol.

b: Full recovery of rCBF demonstrated by SPECT after treatment.

かし，喋ろうとしているが，言葉は聞きとれなかった。あ わてて，119番通報し，救急車を要請した。夜間急病セン ターに搬送された患者は当直医によって血液検査，心電 図，胸写，そして頭部 CT を施行され最後に家族にこう 言った。「脳梗塞と思われます。当センターには脳専門の 医者はいませんので，これから転送します。」奥さんは訳 もよくわからないまま再び救急車に夫とともに乗り込ん だ。私の病院に到着したのは午前 5 時 10 分であった。来 院時, 神経学的にはJCS-30 で右半身麻㿁と全失語症で あった。CT, MRIでは左前頭葉運動前野深部白質に小さ な低吸収域を認めるのみであったが，MRA（Fig. 1a）で は左内頸動脈終末部の閉塞と脳血流 SPECT（Fig. 1b）で 左前頭葉と頭頂葉に著明な血流低下を認めた。2004年度 版脳卒中治療ガイドライン（Table 1）によると，本患者 はいずれにも該当しないというか勧められる治療がない ことになるが，私は症状が徐々に進行していること，高 齢であること, 心電図上異常がないことなどから脳血栓 塞栓症と考え, Et-PA 70万単位を生理食塩水 $20 \mathrm{ml}$ に溶解
し 1 分間で静注し, その後, マンニトール製剤 $300 \mathrm{ml}$ 点滴静注した。すると投与 2 時間頃から徐々に右片麻痺 は改善し, 翌日はほぼ麻痺は消失し, 失語も消失した。翌 日のMRAでは閉塞は完全に消失し（Fig. 2a）, 脳血流量 もほほ回復した（Fig. 2b）。

\section{2. 急性期脳梗塞の治療法の EBM と NBM}

脳梗塞診断と治療のプロコートの流れの幾つかを(Fig. 3)に示した。施設毎あるいは主治医毎に，あるいは症例 毎に各々異なったフローチャートに沿っているものと思 われる。筆者の私も以前は CT の後に脳血管造影を施行 し, 閉塞部位を確認し, 血管内に血栓溶解剂を注入した ころもあった。体力的にはきつかった割には成績がかん ばしくなかった。そこで次世代はCTの後, MRI/MRAを 施行, 直ちに脳血流 SPECT も施行, MRA で脳血管の閉 塞があれば血栓溶解剂を静注し, その後再びSPECT, MRAを施行した。この方法は塞栓・血栓の病態がよくわ かったことと, 治療薬の効果が一目瞭然であった。しか 


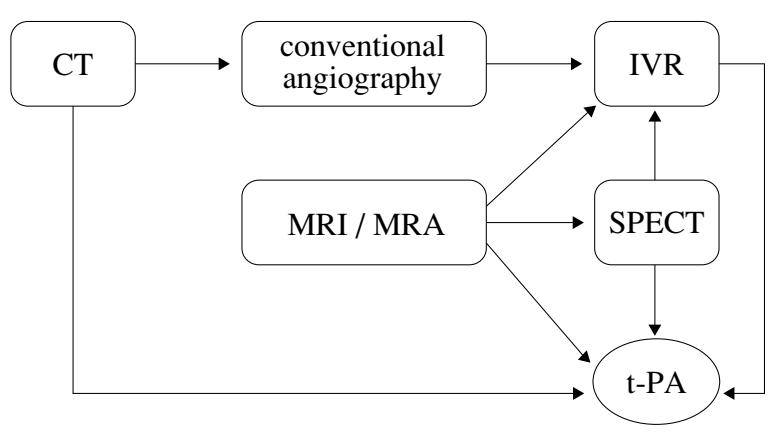

Fig. 3. Various treatments tree for acute cerebral infarction.

し成績は約50\%でIVR と余り変わらなかった。これら約 100例の貴重な経験から現在は発症様式，臨床症状，既往 歴，胸写，心電図などから脳塞栓症または脳血栓塞栓症 が十分に疑われ，CT上，まったく異常がないか，あって も限局した少ない範囲であればCT 撮影直後に $\mathrm{t}-\mathrm{PA}$ 製剤 を静注している。これにより65\%の症例は回復または軽 快した。その後, この方法が発症 3 時間以内という限定 ではあるが厚労省に承認されるに至った。

\section{3. $\mathrm{EBM}$ と NBM の関係}

体に起こる病理学的変化を疾患 (disease) とすればそ れに伴う患者の主観的苦しみを病気 (illness) と定義され る。しかしそ机は医師の立場からであり患者の視線では ない。患者からすると自分を主人公として自分本人に よって語られる「物語」そのものが病気であり，医師は それを患者との対話から理解するしかないのである。言 語から得られないのであれば体の変化からそれを知るの である。言葉・対話・物語 (narrative) を重視する医療の アプローチを narrative based medicine (NBM) という。臨 床の現場における患者の諸問題からケアの方針を決定, 評価する際にエビデンスを検索，吟味すること (evidence based medicine; EBM）は当然であるが，その際に医師と 患者の間にある narrativeをもって配慮して医療がなされ るべきであろう（Fig.4）。

\section{4. 救急医学と救急医療}

医に関する学問を医学とすれば医学的治療の実践を医 療と呼ぶ。すなわち, 救急に関する学問を救急医学と呼 び, 救急的治療の実践を救急医療と呼ぶ。21世紀の救急 医は決して閉鎖された自我としての医療社会の一部に閉 じ込もるのではなく, 医療社会, 一般社会, 世界, 宇宙 へと広がる共同性に開かれた医師として存在するという

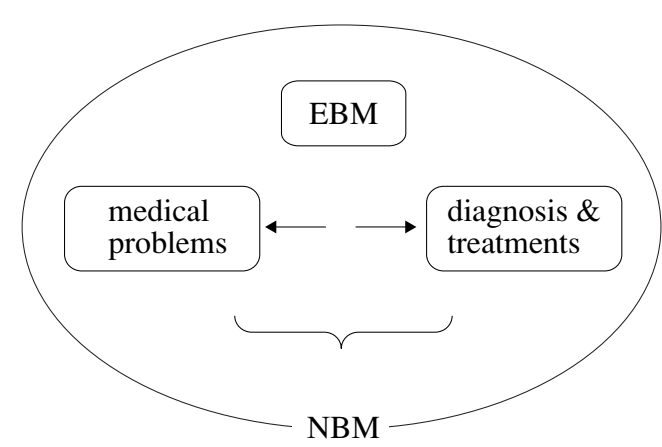

Fig. 4. Relationship of EBM (evidence based medicine) \& NBM (narrative based medicine).

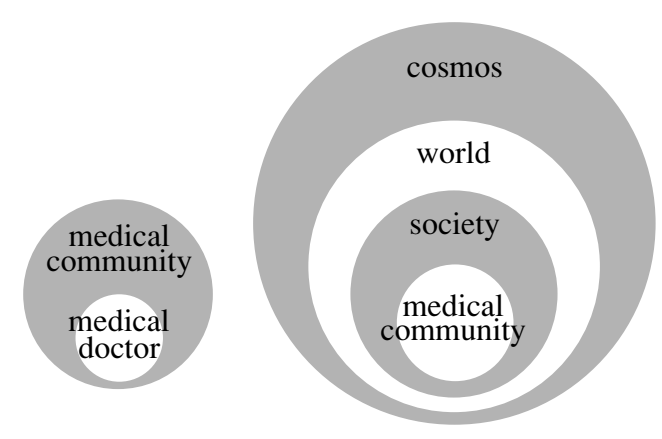

Fig. 5. Identity of acute medical doctor. Left: Old fashioned acute medical doctor being closed egocentric medical community.

Right: New fashioned acute medical doctor being opened for society, world and cosmos.

identityを持ち合わせなくてはならない $($ Fig. 5)。

\section{おわりに}

医師と患者, 家族が共通の情報 (救急医学) を十分に 共有し, 同じ理解基盤に立って意志疎通（救急医療）し ていく，すなわちEBMを包含したNBMが重要と思われ る。救急に携わる私達はもっと narrative になるべきであ る。

謝辞：この本文の内容は平成 18 年 10 月 30 日〜 11 月 1 日福 岡に於て開催されました第34回日本救急医学会総会に於いて 発表したものです。本会の発表とは一部内容が異なり，また 正式な論文の形式をとっておりませんことを深くお詫び致し ますとともに，この拙文が揭載されましたことに深く御礼申 し上げます。 


\section{SW3-2}

\section{外科系集中治療室からみた救急医学, 救急医療と救急医}

\author{
${ }^{1}$ 藤田保健衛生大学病院 SICU（外科系集中治療室） \\ 2 藤田保健衛生大学病院心臓血管外科
}

\begin{tabular}{|c|c|c|c|c|c|}
\hline 貝沼 & 関志 ${ }^{1}$ & 大原 & 義隆 ${ }^{1}$ & 安藤 & $太^{E^{2}}$ \\
\hline 部 & 俊哉 ${ }^{2}$ & 佐藤 & 雅人 ${ }^{2}$ & 服部 & 浩治 ${ }^{2}$ \\
\hline & 竜 ${ }^{2}$ & & 満 2 & 近藤 & \\
\hline & 将人 2 & & & & \\
\hline
\end{tabular}

\section{はじめに}

救急医学, 医療においては近年, 病院前救護, ERの発 展が著しい。一方, 集中治療においては, 各施設の歴史 的経緯から救命救急センターICUだけでなく, 院内に多 様な ICU(内科系ICU, 外科系ICU, CCU, RCU, NICU, 周産期ICU，Stroke care unitなど）を別々に有することに なった施設も多い。このような現状を踏まえて, 救急, 集 中治療, 各科に属する acute physicianないし critical care physicianの連携がいっそう求められていると考える。

\section{1. 当 Surgical ICU（外科系集中治療室）の沿革}

筆者が1979年に名大を卒業した当時, 全国的に救命救 急センターやICUの立ち上げが盛んであったが，筆者の 住む愛知県では，それを担う科は主に麻酔科であった。 同じ愛知県の藤田保健衛生大学 (当時名古屋保健衛生大 学) では同年に救命救急センターを開設していたが,こ こでは主にICUの脳外科医とCCUの循環器内科医が救命 救急センターを担った。彼らは多発外傷を含むすべての 救急患者を受け入れた。とくにICUの脳外科医たちは, 多 発外傷, 中毒症例なども 24 時間体制で受け入れ救命救急 センターを支えた。一方, 筆者の勤務していた名大医学 部附属病院では救急患者の受け入れ体制は十分整わない 時期が続いたが，1988年にようやくICUが開設され筆者 も勤務した。

藤田保健衛生大学では2001年に救急部を開設し, 救命 救急センターの体制が NCU（Neuro Care Unit）, CCU, GICU（general ICU）となり，筆者がチーフを担当する Surgical ICU (外科系集中治療室) を2004年に開設した。

\section{2. 当 Surgical ICU 紹介}

当院Surgical ICUは2004年 6 月 1 日に当初 4 床で発足 し現在 6 床へ拡大している。2006 年 9 月 30 日までで入 室患者数は延べ 480 名である。平均在室日数 6.7 日, 最長 53日, 最短 1 日, 入室患者の疾患別内訳は現在までは心 臓血管外科疾患の重症例が主体であるが, 徐々にその他 の科からの入室を増加させている。Surgical ICUでの死亡 者数は 41 例, 死亡率は $8.5 \%$ である。入室時心肺停止を 含めた最重症例のみの入室であるという因子もあって比 較的高い。術前心肺停止例, 制御できない出血例以外に は敗血症, 腸管虚血, DICなどが死亡原因であり(図1), ここには救命救急センターICUとの共通の学問的臨床的 課題が存在する。

Surgical ICU 入室患者 480 例中 42 例 $(8.75 \%)$ は心臟血 管外科緊急のための ER からの即入院である (図2)。こ れらの症例はすべてショックまたはプレショックでSurgical ICU入室, 手術室準備が整うまでに各種カニューレー ションや気管挿管を施行し, 一部の症例はSurgical ICUで 保存的療法を施行した。このような症例では現場からの 病院前救護の過程で救急救命士らと, ERの過程で救急科 専門医との連携が必然的に生じている。

当Surgical ICUは特定集中治療室管理料を算定している。 朝夕のカンファレンスは日祝を含め必ず行い, 診療におけ る指示出しおよび各種診療手技は専従医が行う closed ICU である。ただし，外科的手技困難例は適宜，外科医の援助 を得ている。図3に主な手技施行例数を示した。

一般に ER や ICU の現場に扔いて, 救急科専門医や集 中治療専門医がそれらの部門を “管理運営”するのみで 実際の具体的な診療を専ら各科に任せるならば, これら の専門医のアイデンティティは失われ, 救急・集中治療 は後退の道を歩むだろう。病院機能評価では患者ごとに 主治医と担当医を明確にするように求めており，これま での当病院の経緯から当 Surgical ICU では主科の医師を 主治医とし, 実際に診療を行うICU専従医を担当医とせ ざるを得なかった。しかしER, ICUでは主治医，担当医 概念はなじまないこと2)を機能評価側も理解すべきであ ろう。ER やICUの専従医が名実ともにその現場で「主治 医」であるように努力することは, acute physicianないし critical care physician のスペシャリティとアイデンティ ティの確立するために, 患者の側からは急性期に責任を 持って診ている医師を明確に認識するためにぜひとも必 要なことである。

\section{3. 救急医からみた重症患者の集中治療}

救急医学は救急来院するすべての救急疾患の診療, 教 


\begin{tabular}{|c|c|c|c|}
\hline 1 & APTEによる心停止 & 22 & 来院時心肺停止, 心不全 \\
\hline 2 & 縦隔炎，敗血症 & 23 & 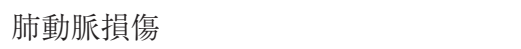 \\
\hline 3 & 敗血症 & 24 & TAAA 後出血. \\
\hline 4 & ASO, 外腸骨動脈 S 状結腸瘦 & 25 & 急性 A 型大動脈解離, 脳死 \\
\hline 5 & 胸腹部大動脈瘤破裂心停止 & 26 & 心不全, 敗血症 \\
\hline 6 & 肺動脈肉腫 & 27 & 肺塞栓, DIC \\
\hline 7 & 敗血症 & 28 & 止血困難 \\
\hline 8 & 縦隔炎, 敗血症 & 29 & 敗血症，多臟器不全 \\
\hline 9 & 敗血症，DIC & 30 & 急性 A 型大動脈解離, 急性心筋梗塞 \\
\hline 10 & AMI, 腎不全, 敗血症 & 31 & 腎不全，腸管虚血 \\
\hline 11 & IE，腎不全，敗血症 & 32 & 下行大動脈瘤破裂 \\
\hline 12 & AAA 破裂，腸管虚血 & 33 & 急性 A 型大動脈解離, 心タンポナーデ \\
\hline 13 & 胸腹部大動脈瘤破裂心停止 & 34 & 急性 A型大動脈解離，敗血症 \\
\hline 14 & 上行大動脈瘤，敗血症 & 35 & 肝不全, LOS \\
\hline 15 & 敗血症, DIC & 36 & 敗血症, 多臟器不全 \\
\hline 16 & 下行大動脈箇破裂, 腎不全, DIC & 37 & 弁機能不全, 心不全 \\
\hline 17 & 敗血症，DIC & 38 & 敗血症，腸管虚血 \\
\hline 18 & 誤嚥, 敗血症 & 39 & 右室梗塞, 急性下肢動脈塞栓 \\
\hline 19 & NOMI, 腸管壊死，敗血症 & 40 & 広範囲脳梗塞 \\
\hline 20 & 敗血症 & 41 & 急性心不全 \\
\hline 21 & 急性腸管壊死 & & \\
\hline
\end{tabular}

図 1 Surgical ICU での死亡原因

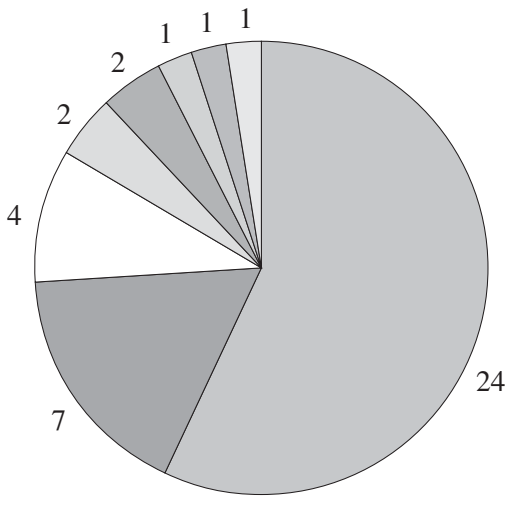

$\square$ 急性A型 $\square$ AAA $\square$ TAAA

$\square$ APTE $\square$ IE $\square$ 総腸骨動脈瘤 $\square$ 急性動脈閉塞

図 2 救急外来から直入 42 例 $(8.75 \%)$

育, 研究を行う医学であり, 病院前救護, ER, 集中治療 の 3 つの分野からなる。救急医学はその一分野である集 中治療に扔いて重症救急患者の診断, 治療, 管理をも目 的としている。一方, 集中治療医学は重症患者の呼吸, 循 環, 体液などの診断・治療, 管理を主目的とする医学で ありそれら重症患者を収容するための病室を集中治療室 という。集中治療室では多くの施設でERからの重症患者 も扱うが, 院内の大手術後患者や院内で重症化した内科

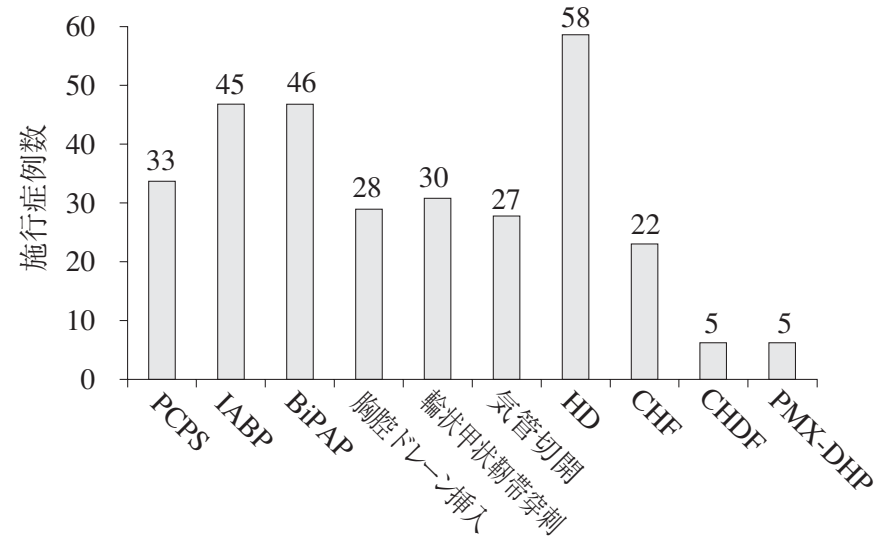

図 3 主な手技施行症例数 (480 例中)

系患者も扱う。その学問的内容および診療内容は多くの 部分が重なっているが，救急医学と集中治療医学は同じ ものではない。救急医学領域における集中治療医学は救 命救急医学と呼ばれることもある。

しかし, 救急医学と集中治療医学の共通性ないし違い を強調することはある場合は有効であるがある場合は有 害である。先に述べた各施設の歴史的事情から救急科専 門医の活動分野は各施設で異なり，それは冒頭に述べた 各種多様なICUの存在とも表裏をなすものである。その 
施設毎に患者救命に最適な救急科専門医の配置こそが最 優先であり, 問題は救急医（学）と集中治療医（学）の 共通性と違いを哲学的に論ずることではない。医学医療 は現場から生じ, 現場から再編されるものであるからで ある。

救急医学会の救急医が院外からの救急患者を除いた院 内重症患者や術後患者にどうかかわっているかの実態に 関する資料がある。2006年の救急医学会雑誌に揭載され た救急部門に関するアンケート調査結果では, 院内発生 の他科重症患者の治療に $33.9 \%$ の救急医が主役として, $33.1 \%$ が参加してかかわっている。他科大手術後の治療 に $12.6 \%$ が主役で $29.9 \%$ が参加としてかかわっている。 理想とする救急医の業務内容を聞くアンケートではおお むね半数の施設で救急医が主役でまたは参加してかかわ ることを理想としている業務内容に他科手術室患者の術 後ICU管理が含まれている。ここには現在の日本の急性 期治療と救急医の業務内容に関する実態が反映されてい る。救急専門医でかつ集中治療専門医である筆者は病院 前救護, ER, 集中治療を含めて Surgical ICU 的な治療も 自己の守備範囲に入れることを理想とするが，これに関 しては救急医各個人や施設の事情で異なろう。筆者の Surgical ICUでは院内で最も重症な外科系重症患者を引き 受けているため, 呼吸管理のみならず, PCPS, IABP, 血 液浄化法, 敗血症治療などを 24 時間 365 日の日常の主た る診療内容としている。広い意味の救急医学の一分野と とらえることも可能であるが, 狭い意味での救急医学の 外に仮に置くとしても，その診療内容は集中治療医学の 最も重要な部分で救急医学と医学医療内容を共通として いることは間違いない。

\section{4. 救急科, 集中治療, および急性期各科専門医の連 携をめざして}

(1) acute physician, critical care physician とは何か。 この問題に対するわれわれの答えは常に具体的である べきである。すなわち, acute physicianないしcritical care physician とは「生命危機にあるいかなる病態においても 蘇生を行いつつ急性期診療を行う医師」ということにな る。例えば, 腹痛の鑑別診断で腹部大動脈瘤切迫破裂を 疑い的確に病診連携を活用できる掛かりつけの開業医か ら, ERで急性期ショック治療を行う救急医, 根本治療を 行う血管外科医，集中治療医のいずれもが言葉の真の意 味での acute physicianないし critical care physicianである。 救急ないし集中治療を従来概念での専門分化した科のひ とつ，つまり閉鎖系の専門科でとらえてはならない。 acute physician や critical care physician は救急ないし集中
治療を行うすべて医療従事者への開放系の中心となる医 師集団である。もしもそのアイデンティティの確立を求 めるあまり救急医や集中治療医が排他的な閉鎖集団と なってしまうならば, 彼らは逆にその存在理由を失うこ とになるだろう。 acute physician や critical care physician になることは同時に個々の医師の人生においても常に内 容が高度化していく generalist と specialistの両方を行き来 して絶え間なく修練することを要求される終わりのない 過程である。

(2)どうすれば患者のための acute physician ないし critical care physician になれるか

個々の医師が acute physician や critical care physician を 目指す過程として, 現在ある救急科専門医や集中治療専 門医を取得するというシステム自体は細部に改善点があ るとしても現在有効に機能している，と思われる。acute physician や critical care physicianは互いの subspeciality へ の敬意を払うと同時に, 境界領域については evidence と experienceに基づいて真摰に討論と診療上の協力を行うこ とが，信頼に満ちた連携を深める上で欠かせないことで ある。個々の acute physicianないし critical care physician はこのために常々，自らの subspeciality だけでなく境界 領域である医学医療全般について学習しておくべきであ る。ここで最も大切なものは個々人の勤勉さと医療従事 者間を連携できるキャラクターであり，これに欠ける者 は acute physician や critical care physician に向かない。

(3)連携は on-the-job と off-the-job で

acute physician や critical care physician は常に「頭の先 から足の先まで」徹底的に診察するので，専門分化した 他科の医師にも援助を求めることになる。しかしこれは, 自己の守備範囲外の問題を他科に「任せて」しまうこと ではない。「任せて」しまえば「全身を診る」acute physician や critical care physicianの診療が「全身」という名の部分 を診ることに追い込まれる。他科の診療の専門性につい て常に学習しまた敬意を払うという姿勢が他科の医師か ら診療に有効な援助と協力をいただける前提である。 acute physician や critical care physician からの依頼に特別 の興味と感心を示していただける他科の医師が多いこと は日常的に経験する。専門分化したいずれの科もその分 野に急性期重症期診療の内容を有しているからであろう と想像される。

次に必要なのは, off-the-jobの連携であるが, これは医 師個々人の自発的・意識的な努力を必要とする。学会活 動だけでなく, 各種BLS, ACLSコースやJATEC, JPTEC コースの受講やインストラクションを通じての連携の広 がりは, 数年前と比較すると隔世の感がある。先進的に 
この分野を切り開いてこられた，草の根のacute physician Pcritical care physician, また救急医学会などの学会指導 者たちの努力の賜物である。ただし, off-the-jobの活動は 常に on-the-job のために存在することを忘れてはならな w。

\section{5. 救急医療と表裏をなす救急医学体系の確立をめざ して}

筆者が名大を卒業した1979年頃，名大方式のスーパー ローテート研修は全国でも珍しかった。しかしそのシス テム下でも「専門分化された各医局の守備範囲を超えて 幅広く救急, 集中治療, ないし総合診療の修練を積むこ と」は，筆者の周辺では殆ど不可能であった。そのなか で, 救急, 集中治療や総合診療の優れたシステムを敷い ている施設を全国に見つけ，「医局を離れて」努力した人 たちもいる。筆者はそれ程ではなかったが, 麻酔科に属 しながらも許された時間は外科や一般外来診療に割くと いう典型的でない麻酔科生活を送りながら，なんとか内 因的要求を満たしていた。結果として現在その経験は大 いに役立っている。そして，今になって，現在最も必要 とされているのは「救急総合診療医」であり, 研修医教 育の中心となるべきそれらの医師たちが日本に育ってい ない現状が指摘されている。しかし実際には，20数年前 からそれを目指し努力していた個々人は医療現場に多く 存在していたが，医局講座制や専門分化の大きな潮流の なかで自己実現を遂げることは多くの場合困難であった と考えられる。しかし，わが国の医療の歴史を振り返る ならば，その時代はまさに専門が専門としての内容を高 度化することのほうが要請されていた時代であったこと にも理解を向ける必要がある。

筆者が高校生であった1970年前後世代の多くは，学問 や社会のあり方を問うて世の中の矛盾に正面から立ち向 かった経験をもっている。その後30年以上を経て, acute physician, critical care physician として患者さん・ご家族 と, 人生の生と死にかかわる喜び悲しみを共有すると, 医師という外面的「肩書き」を遥かに超えて, 自分自身 の生の意味に時々媣く感じ入ることがある。救急医学会 に扔いても, 病院前救護, ERだけでなく集中治療室や時 には術後重症患者の集中治療室でも働く acute physician, critical care physicianたちとの学問的専門的討論の合間に, 患者救命への情熱を分かち合えたらどんなにいいだろう かと思っている。救急治療, 救急医学の内容はその時代 に置かれた急性期重症患者と患者救命への努力によって 時代とともに作られるものであり，時代とともに再編さ れ固定化することを知らないものである。

\section{SW3-3}

\section{救急医療における臨床倫理学の 確立を目指して}

\author{
大阪大学大学院医学系研究科救急医学, \\ 附属病院高度救命救急センター
}

田中 裕 松嶋 麻子 田崎修
杉本 壽

\section{はじめに}

救急医療は “医” の原点であり，かつ，すべての国民 が生命保持の最終的な拠り所としている根源的医療と位 置付けられる（厚生省救急医療体制基本問題検討委員会 報告書, 平成 9 年 12 月 11 日発表)。本発表ではその救急 医療と表裏をなす救急医学とは何かについて論じ, その なかで昨今重要性が高まっている臨床倫理学の位置付け について解説する。

\section{救急医療と救急医学}

原始の時代から人類にとって医療の最大の課題は, 外 傷や急性感染症などの急性病態であった。洋の東西を問 わず多くの人命が急性病態で突然失われたことは歴史が 示す通りである。わが国の死亡統計の推移をみれば，数 十年前までは急性病態が死因の上位を占めていたことが わかる。このように人類は突然襲う急性病態に絶えず脅 え続けてきたのである。この人類最大の課題である急性 病態を扱うのがまさに救急医療である。救命救急医療で は限られた時間と方法しかない場合がある。とにかく目 の前に迫った死を避けることが最優先になる。まさに命 が失われようとしているとき，あらゆる可能性に挑戦す るのが救命救急医療である。通常は, 手術中の死は外科 医の最大の恥とするところである。だが，救命救急医療 は何もしないで患者を死なせるのが最大の恥である。た とえ $1 \%$ の可能性にも挑戦しなければならない厳しい状 況がある。そしてそこにこそ救急医療の面白さがある。

一方, 救急医療を支える基礎が救急医学研究である。 したがって, 救急医学の範囲は非常に広範囲に及ぶ（図 1)。救急医学ではあらゆる急性病態を扱う。急性病態は 恒常性を乱す突然の侵襲によって引き起こされる。侵襲 


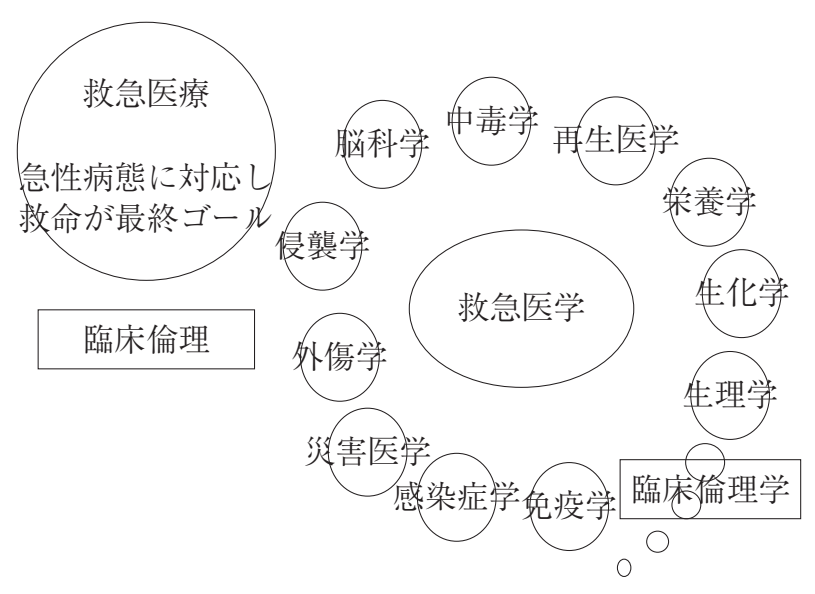

図 1 救急医療・救急医学と臨床倫理

の種類や程度などによって表に現れる症状は様々である が，いずれの侵襲に対しても生体は質的に共通の反応を 示す。この急性病態に抢ける生体反応の解明, すなわち 侵襲学は救急医学のきわめて重要な領域である。重症救 急患者管理の本質は, 病態解析に基づき生体機能を外部 から調節することにある。ショックを例にとれば，発生 機序を明らかにすることが治療法の選択で決定的に重要 である。これは科学的問題解決手法そのものであり，ま さに救急医学である。救急医療では危機管理と decision makingが不可欠である。これらは単に個人の経験に頼る かぎり進歩はない。危機の種類や状況は様々であるが, 共通の原理・原則がある。危機管理学, decision making 学, さらには集団災害医学も救急医学の重要な領域であ る。“いつでも，どこでも，だれでも適切な救急医療を” 実現するための救急医療システムはいかにあるべきか, これも重要な研究テーマである。医療は一般に社会性を 無視しては成り立たないが，とりわけ救急医療は社会性 が高い。賠償医学, 医療経済学, 社会保障システムなど, 救急医療の関連領域はきわめて広い。これらの問題を解 決するうえで，実学としての救急医学が果たす役割はき わめて大きい。実践としての救急医療と実学としての救 急医学とは，互いにpositive feedbackをくり返し，相互発 展する関係にある。

\section{救急医療における臨床倫理学の確立を目指して}

近年のめざましい医療技術の発展は医療の可能性を飛 躍的に高めてきた。救急領域でも人工呼吸器や脳蘇生法 などの医療技術の進歩の結果，今まで救命が困難であっ た症例を助けることが可能になってきた。しかしこれに 伴い回復の見达みのない患者に対して延命治療を続ける 場合も増えている。こうしたなか，回復の見込みのない
状態で延命措置を受け続けるよりも，むしろ延命治療を しないで自然なままに, 苦痛はできるだけ軽減して安ら かな死を迎えたい，尊厳を失うことなく最後を迎えたい (尊厳死) と希望する患者もいる。自分の意思で自分の死 に方を決める(死の自己決定)という考え方が，患者の権 利という概念とともに広がってきたことが社会的要因と して考えられる。救急医療では, 最初に「Rule of Rescue」 の考えがあるため，治療の中止は「敗北」と考えられてき た1)。しかし, 回復が望めない場合や, 救命出来ても遷延 性意識障害が持続する場合など，「救急医療は本当に救命 だけが最終ゴールなのか? 」という疑問が生じており，終 末期医療に対する知識の整理や教育の必要性が高まって いる。具体的には, 救急医療の適応や cure から careへの アプローチ, Rule of Rescueとしての救命医療の必然性, 倫 理·法律的側面，様々な症状に対する方針決定，患者·家 族とのコミュニケーションなど，救急医療従事者に課せ られた問題は多い2）。さらに，救急·集中医療では重装備 の医療展開が行われてきたが，この領域における医療費 の増加が問題となっており, 最近になり「救急・集中医療 に抢ける医療資源の制限」についての研究も精力的に行 われている3)。

米国では1960年代に始まった人権運動と連動して，医 療の分野にも革新的な運動が起こった。すなわち患者の 意思を尊重しなかった従来の医師の態度や行為に対する 批判や，患者のなかにも治療を医師任せにしないで，自 己の意思によって決定しょうという気運が高まってきた。 ヒポクラテスの誓いの「医師は自分の能力と判断に基づ いて医療を患者のために行い，決して害になるものを与 えない」というだけでは，たとえそれが患者に良かれと 思ってなされたとしても，患者の意思を無視したものに なり，「医師は患者に良く説明して，患者が理解し納得し た上で進んで受けたいと思う医療を行う」ことが必要に なってきた。このような働きに呼応するかのように， 1970年頃より医療の倫理的問題について検討されるよう になった。その後, 臨床現場でも医療スタッフを中心に, 実際の臨床で役立つ医療倫理を目指そうという流れが出 てきた。Jonsenらによって1982年に「Clinical Ethics」が 出版され, 1990 年に臨床倫理の専門雑誌 The Journal of Clinical Ethicsも出版されるようになり，この分野の教育， 研究は着実に進められてきた4)。その後Clinical Ethicsは 日本語に翻訳され, 「臨床倫理学一臨床医学における倫理 的決定のための実践的なアプローチ」というタイトルで 出版された ${ }^{5)}$ 。臨床倫理は「患者（家族）と医療関係者 が，日常的な個々の診療において発生する倫理的な問題 点について，拈互いの価値観を尊重しながら，最善の対 


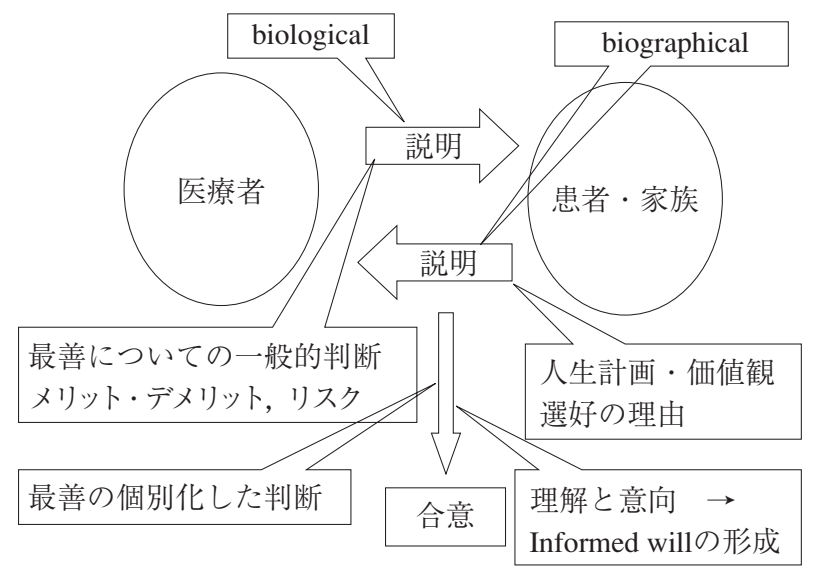

図 2 意思決定のプロセス（情報共有一合意モデル）

応を模索していくこと」と定義される。通常，医療者側 は患者・家族に治療方針等の説明を行う場合，この考元 方に基づいて説明を行ってきた。しかし前述したように， 医療技術の進歩により延命治療の継続が可能となる中, 尊厳死を望む患者・家族にどのように対応するかが医療 者に求められている。また医療の複雑化と危険性の増大 により医療の質と安全が脅かされ，医療への信頼が大き く摇らいでいる。このような状況を鑑み，今一度臨床倫 理の立場に戻って医療展開を行う必要がある。

われわれは現在救急領域における臨床倫理問題を検討 するために，東京大学清水哲郎先生が開発された臨床倫 理検討シートを用いた臨床倫理検討会を行っている。検 討シートの詳細は論文を参照していただきたい。ここで は図2のようなプロセスを重視している6)。すなわち，治 療方針などの意思決定のプロセスとして，「情報共有一合 意モデル」あるいは，「informed willの形成」という考え 方を取り入れている。まず医療者側は生物学的（医学的 な見地から）最善についての一般的判断，メリット・デ メリットについて患者・家族に説明する。これに対して, 患者・家族は，その人の今までの生活や人生計画，価値 観をもとにbiographicalな立場から医療者側の説明に対し て話をする。この時点で双方の意思決定に合意が得られ た場合はいいが，そうでない場合にさらなる話し合いが
必要となる。医療者側は最善についての個別化した判断 を提示する。一方, 患者・家族はそれを理解し, 自分達 の意思を表明する。その間，医療者間，患者·家族間，医 療者・患者・家族間で話し合いがもたれ, 問題の解決と 合意が目指される。

\section{結語}

救命医療の現場では，急激な発症や，治療選択までの 時間が非常に短いなど, 特殊な状況のなかで治療選択を 余儀なくされる場合が多くある。そのなかで今までのよ うに救命第一の治療が最優先されるのではなく, 患者自 身の価值観，尊厳が最大限に尊重される治療が今後さら に求められていくと考えられる。様々な価值観が混在す る今日, 患者が選択する医療ということが重要となって くる。そのなかで, 臨床倫理とはどのような視点で考え ることなのかを救命に携わるスタッフが熟知することが 求められている。そのためにもこの臨床倫理検討会は非 常に有意義なものであり, 今後さらに検討会を継続し, 救急医療のなかの臨床倫理, 救急医学における臨床倫理 学とはなにかを追求していきたい。

\section{文献}

1) Hadorn D: Setting health care priorities in Oregon: cost-effectiveness meets the rule of rescue. JAMA 1991; 265: 221825.

2) Mularski RA, Bascom P, Osborne ML: Educational agendas for interdisciplinary end-of-life curricula. Crit Care Med 2001; 29 (Suppl): N16-23.

3) Truog RD, Brock DW, Cook DJ, et al: Rationing in the intensive care unit. Crit Care Med 2006; 34: 958-63.

4) Jonsen AR, Siegler M, Winslade WJ: Clinical Ethics - A practical Approach to Ethical Decisions in Clinical Medicine (3rd ed.). McGraw-Hill, New York, 1992.

5）赤林朗, 大井玄: 臨床倫理学: 臨床医学における倫理的 決定のための実践的なアプローチ. 新興医学出版社, 東 京, 1997.

6）清水哲郎, 伊坂青司:生命と人生の倫理. 放送大学教育 振興会出版, 2005 年, p177-87. 


\section{SW3-4}

\section{救急医療の現場に打ける終末期医療のあり方}

杏林大学医学部救急医学

小泉 健雄 山口 芳裕

\section{はじめに}

2006 年 4 月明るみに出た富山・射水市民病院の「人工 呼吸器外し事件」等を契機に終末期医療に対する延命治 療をめぐり社会的な注目が集まっている。いずれも意識 がなく回復の見込みがない状態であるが末期患者 7 人の 人工呼吸器を外し, 全員が死亡本人の同意書はないが, カルテには「家族の同意」を示す記述だけがあった。

病院側の見解としては積極的安楽死ではなく, 延命治 療措置の中止の範疇とされた。

ただし患者本人の意思が明確であったかどうか，他の 医師に相談するなどの手続きを十分にしていない。病院 側の判断で警察に届けたところ富山県警が殺人容疑によ る立件を検討したといういきさつがある。2006年10月現 在，殺人罪適応は微妙な状況であるが，このトピックス 以後，終末期医療のあり方について賛否両論渦巻いてい るのが現状である。この事例をうけ，厚生労働省を中心 として延命治療中止についてのガイドラインあるいは法 的整備の動きがあった。2006年10月，回復見込みのない 終末期の患者に対する治療中止のガイドライン試案が発 表された。そこでは本人の意思が確認できないケースに おいては家族の話から元気だったころの患者の意思を推 定する。家族不在あるいは意見が分かれる場合は医療 チームの判断に委ねるというものであった。

また，日本集中治療医学会の調査では集中治療室 (ICU) の医師 $90 \%$ が，過去一年間に回復見込みのない患 者の延命措置について積極的に行わなかった経験がある と報告された。内訳としては現状維持39\%, 減量治療 28 $\%$ ，部分的中止 $27 \%$ ，すべて中止は $4 \%$ であった。

救急医療の現場においても医師が延命治療に対して常 に重大な決断を迫られる。わが国の医療界の一般的な認 識として当該患者について

1. 生命維持が困難な不可逆的病態である

2. 積極的延命治療継続の妥当性がない
3. 1, 2 について本人あるいは家族から informed consent の取得がなされ同意文書が存在する以上がこの問題 に対する最低の条件と言える。

\section{調查目的}

今回われわれは救急医療における終末期医療に関して 何らかの「指針」つくりが必要か否かそのための基盤調 査として現状分析を行った。

\section{対象と方法}

施設：杏林大学高度救命救急センター, 期間 : 2005 年 1 月 2006年 4 月, 対象: 全入室患者 2,214 人, 内DNAR orderが指示された 128 人，積極的延命治療を最後まで続 けた 20 人

\section{当施設における標準的 DNAR order}

病態の回復見込みがないと判断された場合，以下を十 分なinformed consent取得の上，以下を指示する背景因子 および医療費について

1. 心停止時, 心臓マッサージを試みない

2. 急激に血圧が下がった場合，昇圧剂を新たに使用 しない，あるいは増量しない

3. 呼吸が停止，著しい呼吸障害に陥った場合，気管 挿管しない，人工呼吸器を装着しない，あるいは 人工呼吸器の設定を上げない

背景因子として医療費以外はDNAR群と非DNAR群は 差がなかった。

\begin{tabular}{lccc}
\hline & 平均年齢(歳) & $\begin{array}{c}\text { 救命センター } \\
\text { 入院日数 (日) }\end{array}$ & $\begin{array}{c}\text { 医療費 } \\
\text { (点) }\end{array}$ \\
\hline DNAR order 群 & $72.16 \pm 13.66$ & $11.65 \pm 13.05$ & 3.4 万 \pm 1100 \\
積極的治療群 & $65.22 \pm 11.71$ & $15.73 \pm 9.00$ & 11 万 \pm 18020 \\
\hline
\end{tabular}

DNAR order を考慮した理由

\begin{tabular}{lc}
\hline 臨床的脳死 & 36 人 \\
高度意識障害 $(\mathrm{GCS} 5$ 点以下) & 73 人 \\
重症敗血症 & 14 人 \\
慢性閉塞性肺疾患終末期 & 3 人 \\
\hline
\end{tabular}

DNAR order 指示をうけた 128 人の内訳として

同意書内に DNAR orderについて具体的に記載あり 82 人 DNAR orderについて具体的に記載された同意書なし 36 人 
シリーズ・ワークショップ

さらに同意書のなかった 36 人の内訳として以下に示す。

$\begin{array}{lc}\text { カルテにのみDNAR 記載 } & 30 \text { 人 } \\ \text { 文書内には詳しい病状説明あるものの, DNAR order } \\ \text { は指示簿のみ }\end{array}$

DNAR orderが呈示されているにもかかわらず以下のよ うな事例があった。

- 同意書内に「延命治療中止」あるいは「自然経過 に任せる」など曖昧な表現あり

- DNAR order $(+)$ にもかかわらずカテコラミン増 量, 気道確保のためエアウェイ挿入

- DNAR order $(+)$ にもかかわらず，その後病状回 復L DNAR 撤退 (1 例)

- 家族が処置を望まず救急外来の時点でDNARとな る(1例)

\section{考察}

呼吸器を装着することと外すことは生命倫理，医療倫 理的には同じことである。外すことだけがなぜ問題とな るのか? 一部の施設で拙速なマニュアルづくりが行われ ている。たとえ，救急医であっても個々の患者の状態に 合わせる必要があるのではないか？

人類は近代～現代にかけて，西洋的な究極的合理主義 に基づき科学を発展させ医療を充実させてきた。救命し 得る「生命」が増えたことは間違いないが，反面，生物 学的な生命維持が倫理的問題をはらむことを忘れてはな らない。われわれ救急医は, 生命維持可能なすべての患 者に対し父親的温情主義（paternalism）を基盤とした積 極的治療を続けていくのか?あるいは生命倫理に基盤を おいて救急医療における緩和ケア (palliative care) を模索 すべきか？

また，現代日本人の「死」に対する考え方についても 問題提起できる。江戸時代〜近代にかけて「死」は日常 にあった (1950年代は在宅死 8割)。戦後，病院を中心 とする中央集権的な医療により救命できる「生命」が増 加した同様に「死」の現場も病院となった。必然として 「死」は packing されたものとなり, 近親者の病院死にい きなり直面する事態を招いた。実は日本人全体が「死」に 対する覚悟はおろか考えすら希薄なのではないだろうか。

\section{提 言}

DNAR order の informed consent を得る際には，回復見 込み可能性が著しく低いことを回数と時間をかけて説明 すること, 加えて同意書, カルテにDNARのオプション (心臟マッサージの有無, カテコラミンの減量・中止, 抜 管後の再挿管の有無など）を必ず記載することが必要で あると考えた。個々の患者の状態を把握するとともに， 家族の意向に対応する必要があり，一律な判断や指針は 「患者中心の医療」「informed consent」の精神に反するの ではないかと考える。したがって，現段階では細かいが イドライン作成や法的整備は十分な議論がなされてから 行われるべきであろう。

\section{SW3-5}

\section{京都に打ける DMAT・災害拠点病院 合同研修会の試み}

\author{
京都第一赤十字病院救命救急センター
}

池田 栄人

\section{はじめに}

本来, 救急医療と災害医療は別の医療体系であり, 救 急医学と災害医学も別の学問体系です。日本には災害医 療・災害医学を専門とし専従化した医師集団が拐らず, 既存の救急医が災害医療も担う体制となっている。した がって, 救急医にとって災害医学は大切な領域であり, 大規模災害時に救命を主眼とした初動期対応の実現化を 図るための学問としてとらえられると考えられる。いつ 起こるかわからない災害だが，インフラストラクチャー としての救急医療体制と災害医学に裏打ちされた災害医 療体制が整備されていないと, 失わなくてもよい多くの 命を失うことになり，社会としていかに備えていくかが 問われている。

京都は近年の大禍と問われれば「応仁の乱」(1467 年) と呪談が交わされるくらい，幸いなことに大きな災害に 見舞われていない。その京都で, 災害拠点病院として継 続的に訓練・研修会に取り組んできた。継続的に取り組 
めた要因として赤十字病院であることが大きいが，国の DMAT構想により大きな転換期を迎えている。今回，「京 都府DMAT ・災害拠点病院合同研修会」を試み，その意 義について検討しましたので報告する。

\section{研修会開催の背景}

阪神淡路大震災後, 都道府県に災害拠点病院が整備さ れ，当院は京都府の基幹災害医療センターに指名された。 そのため, 従来の赤十字病院 (3 病院) の災害救護訓練 に加えて, 京都府災害拠点病院（7病院）を対象とした 研修会を合同開催してきた。毎年開催されたその概要を 下記に示す。当初はメイクアップされた模擬患者の受け れ訓練が中心であったが, トリアージ, 病院前除染, 外 傷初期診療などの研修会形式に発展した。

ところが，2006年，赤十字病院がDMAT指定医療機関 を辞退した状況で, 災害拠点病院を対象としたDMAT研 修がスタートしたため, 混乱を生じた。京都府内での一 元化を図るため協議した結果, 2006年の災害拠点病院研 修会はDMAT研修の伝達講習会として合同開催すること となった。

〈京都府災害拠点病院訓練および研修会〉

第 1 回 備蓄と今後の方針（1998）

第 2 回 現実的な訓練 パニック！（1999）

第 3 回 パニックへの対応訓練（2001）

第 4 回 集団災害トリアージ研修会（2001）

第 5 回 時間外での対応訓練（2002）

第 6 回＼cjkstart除染についての研修会 (2002)

第 7 回 除染と現状体制の検証訓練（2003）

第 8 回模擬患者を用いたトリアージ研修会

第 9 回 集団災害トリアージとバックボード搬送

(2004)

第 10 回 救護現場でのトリアージ, JPTEC, AED, 無 線連絡研修会（2005）

\section{研修会概要}

第 1 回京都府DMAT · 災害拠点病院研修会は, 2006年 1 月 21 日（土）, 22 日（日）の 2 日間, 災害拠点病院 赤十字病院から医療班 10 チーム（1 チーム：医師 1 名, 看護師 2 名, 事務 1 名, 計 37 名) を集めて開催された。 京都府医療室, 京都第一赤十字病院, 京都市消防局が共 催し, DMAT研修を受けた医療機関のスタッフ, 赤十字 病院, 京都JPTEC・JATECインストラクターおよび受講 者(計58名)が運営に携わった。研修会のレジメはDMAT
研修プログラムを参考にし以下のような内容とした。

〈第 1 回京都府DMAT ・災害拠点病院研修会プログラム〉

第 1 日 (1)講演:DMAT研修報告

(2)講演：災害医療概論（CSCATTT）（50分）

(3)シミュレーション実習:京都で集団災害 が発生した時

(90 分)

(4)スキル実習：BLS+AED

(5)スキル実習 : 外傷初期診療 (JPTEC)

第2 日 (6)スキル実習:無線連絡

(30 分)

(7)スキル実習:STARTトリアージ (30 分)

8)スキル実習 (30分)：職種別

医＼cjkstart師：JATEC（プライマリサーベイ）

看護師：ナースのためのトリアージ(二次)

調整員：ロジスティックス

(9)シナリオ診療実習: 救護所でのトリアー ジ

(30 分)

(10シナリオ診療実習：救護所での外傷初期 診療

(30 分)

(11)シナリオ診療実習：がれきの下の医療

(60 分)

(12)アンケート・反省会

\section{アンケート・事後検証会の結果}

訓練終了後, 参加者へのアンケート調査と事後検証会 を開催した。

アンケート結果より, 参加者の背景としては, MIMMS について知っていた $19 \%$, ACLS 受講率 10\%, JPTEC受 講率 $4 \%$, JATEC 受講率 $2 \%$ と低率であった。講義・又 キル実習・シナリオ診療実習の評価を 5 段階評価の「5： 非常に良かった」「4:良かった」以上の比率で行うと,「講 義」 $82 \%, 「 \mathrm{BLS}+\mathrm{AED}\rfloor 79 \%$,「外傷初期診療」79\%, 「START式トリアージ」92\%,「JATEC」100\%,「ナース のためのトリアージ」90\%,「ロジスティックス」42\%, 「無線連絡」87\%,「救護所でのトリアージ」81\%,「救護 所での治療」79\%,「がれきの下の医療」90\%であった。 「ロジスティックス」42\%以外は良好と考えられた。総合 評価は $95 \%$ と高く, 京都府下で集団災害が発生した時, 消防の安全管理の下, DMAT · 災害拠点病院・赤十字病 院の救護班が連携して活動していく方向性が確認された。

事後検証会で得られた課題と対策については, (1)各医 療班の服装がばらばらで, 集結したときの服装を統一し, 現場での医療指揮官を明確にする。(2)消防組織は市町村 単位であり, 現場ごとで対応する消防が異なる。京都府 
下で横断的な活動を行うためには, 府下全域の消防組織 の参加が必要である。(3)指揮命令・安全確保のため, 医 療班間の無線機の統一は必要で, DMATチームの無線機 を赤十字病院の医療班に支給し, 一本化を図る。(4)事務 調整員に対するロジスティックス研修について見直しが 必要で,ノウハウの蓄積のある赤十字組織に新たな展開 をお願いする。(5)事前学習がなされておらず単なる JPTEC/JATECミニ講習会になってしまったのでので, 次 回は事前資料を配布し事前学習を促す。

\section{考察}

災害医療において，「災害に備える」ことは重要だが, 災害拠点病院における継続的な訓練・研修会開催などは 一部の地域を除き十分行われていないのが現実である。 その原因として, 多くの医療機関に抒いて事務調整員が 数年ごとに職場変更となり, ロジスティックスのノウハ ウが蓄積できないことがあげられる。当院が災害拠点病 院研修会を継続できたのは, 赤十字支部組織によるロジ スティックスに負うところが大きいと考えられる。また， 全国に基幹災害医療センターの指名を受けている赤十字 病院が10施設あり,メーリングリス卜による医師間の情 報交換がモチベーション維持に貢献していると考える。

災害拠点病院からの研修会参加者は自ら志望しての参 加は少なく, 病院業務として派遣された一般の医師・看 護師・事務職員と考えられる。したがって, JPTEC·JATEC コースの受講どころか事前勉強も不十分であり, 災害研 修会がJPTEC・JATEC 体験ミニコースとなってしまった ことは否めない。しかし, 参加者からの評価は高い。災害 拠点病院が地域の救急医療の中核であり参加者はその担 い手であることを考えると, 災害研修会の定期開催は日 常救急医療のレベルアップに多いに貢献していると考え られる。過去の災害研修会で啓発されて JATEC・JPTEC コースを受講したものもおり, 災害研修会の役割は大き い。

災害医療の場合, 災害医学的見地からのアプローチも 必要である。様々な状況でのトリアージ, 限られた医療 資源のなかでの診療, 特異な環境での医療行為, ハプニ ングに対する危機管理などである。研修会ではシナリオ 診療を実習に織り込み, 体験として好評であったが, 運 営スタッフ・受講生ともレベル差が大きく, 質の評価ま
で至らず，今後の課題となっている。

消防との事後検証会で判明したことは, 立場の違う医 療班が集まった時のチームとしての脆弱性である。医療 班間のユニフォームが不揃いで, 職種・司令官がはっき りせず，連絡・指揮命令系統が不明確である。ユニフォー ムについては赤十字病院の「赤」と京都DMAT医療機関 の「緑」にまとめ, 連絡体制についてはDMAT医療機関 の無線機を赤十字病院にも配備し, 統一化を促進するこ ととした。複数の医療班が集結したときの現場医療指揮 官の選出は大きな課題で, 肩書きだけの当て職では現場 指揮官としてふさわしくない。災害研修会を重ねていく なかでその資格を問い，顔の見える秩序を築いていくの が現実的ではないかと考える。

医療班は消防の安全管理下で現場活動を行うが, 消防 は市町村単位であり現場ごとで対応する消防が異なる。 がれきの下の医療などでは連携や安全確保に格差が生じ る可能性があり, 医療班だけでなく連携する各消防組織 への伝達講習も必要なことが指摘された。次回より府下 の各消防組織も参加する予定となり, 今後, 益々, 災害 研修会の意義が大きくなると考えられる。

厚生労働省が考える現状の DMAT 派遣は, 東京直下 型, 東海, 東南海大地震が主な対象であり, 地域の局地 的災害に対しては地域でのDMAT派遣の計画・協定を結 ぶことになっている。この「地域DMAT」の代表が東京 DMATであり, 神戸, 大阪, 埼玉, 神奈川など拡大して いる。京都でも, 列車脱線やテロ災害などへのDMAT派 遣の連携訓練が開始されているが, 身分保障の問題など より協定締結までに至らず実行性に疑問が残る。救急医 療体制, 地域の DMAT 体制, 国の DMAT体制の 3 体制 が揃ってこそ災害医療体制が整ったと考えられ，地域の メディカルコントロール協議会を巻き込んだ「地域 DMAT」体制確立が現在の重要課題と考える。

\section{おわりに}

以上，DMAT伝達講習会としての災害研修会は，(1)継 続して災害に備えること, (2)べースとなる救急医療の普 及, (3)連絡・指揮命令系統の確立, (4)消防との連携, (5) 地域DMAT体制の確立, などの点で意義があり, 災害医 学と救急医学の接点として重要であると考えられた。 


\section{総括 1}

東京女子医科大学救命救急センター

鈴木 忠

本ワークショップでの 5 名の演者による指摘は以下の ごとくである。

(1)誠友会南部病院脳神経外科 上田 孝

救急医療では EBM，クリニカルパスが導入されても NBM（narrative based medicine）の重要性に変わりはな い。他診療科医や他医療業種とのチームワーク医療を進 めるべき救急医療においてはもっと narrativeになるべき であり，救急医学教育にも反映すべきである。

(2)藤田保健衛生大学 SICU 貝沼 関志

一次から三次まで, さらに高度救命救急医療まで担当 する救急医療を専門分化した一つの科として捉えるべき でない。救急医はgeneralist と specialistの両方を兼ねるべ きであり，その裏付けである救急医学は範囲の限られた 狭い領域の専門的なものであってはならない。

(3)大阪大学大学院医学系研究科救急医学 田中 裕 救急医療においては倫理的対応が重要であり, 治療方 針の決定や診療上の問題点の解決に際し, 演者らの作成 した臨床倫理検討シートは有益であった。救急医療の場 には臨床倫理学を確立すべきである。

(4)杏林大学医学部救急医学 小泉 健雄

終末期延命治療のなかで, どの時点で DNR order とす るか問題提起をした。実際の経験例につき検討した結果, 救命センター入室期間, 死亡までの期間, 医療費などで DNR order 患者が有意に低かった。高齢化の進行, 医療 費の限界が社会的に問題となっているわが国の現況にも 鑑み，救急医学において DNR も考えるべきである。

(5)京都第一赤十字病院救命救急センター 池田 栄人 京都府下の 7 災害拠点病院と 3 赤十字病院で開催され てきた災害拠点病院研修会の内容と問題点につき報告し た。その結果, 集団災害時に消防の協力下に救護班が連 携して活動するための方向性が確認され有用であった。 今後も定期的開催が必要である。

\section{〈討論の内容〉}

上田は救急医療の実態から救急医学教育のあるべき姿 を述べ，貝沼は救急医療と救急医学のあり方を述べた。
田中は倫理的視野から救急医療と救急医学のあり方を, 小泉は終末期医療におけるDNR orderの意義と問題点を, 池田は災害時DMATの活動と, そのための教育, 訓練の 必要性を述べた。

いずれも救急医療, 救急医学を一定の視点で検討した ものである。一言に救急医療, 救急医学といっても, そ れを担当する施設の背景, あるいは担当者の専門性と立 場により，その捉え方が大きく異なることが明らかと なった。この意味では救急医療, 救急医学のあり方を巨 視的に議論する場となる共通の土俵はまだ確立されてい ないといえる。そうはいっても, 施設ごとにあるいは担 当者ごとに独断的に考元, それを押し進めることは大き な問題となる。いまや自分以外の実情と問題点を知り, 互いの立場を理解して考えることにより, 一定の土俵を 確立す心゙きであろう。その段階では立場が異なり，かみ 合わない議論になろうとも，それを繰り返すことにより 共通の概念ができ, そこで初めて救急医療とはなんぞや, 救急医学はどうあるべきか, という巨視的検討ができる ことになる。

このような意味で今回のワークショップは, これから の救急医学教育を考え, 確立するためのよき機会であり, 企画立案した学会長の意向に多少でも沿ったものであっ たと考える。

\section{総括 2}

岡元 和文

シリーズワークショップは, ワークショップ 1「救急 医の役割」, ワークショップ 2 「救急医療教育」を経て, ワークショップ 3 「救急医療と表裏をなす救急医学大系 の確立をめざして」で救急医学を大系化するための糸口 を見いだそうとしたものである。

救急医療の基盤にあるものは救急医学である。基盤と しての救急医学が確立していなければ救急医療や救急医 学教育を科学的に解析し, 上り効果的な救急医療・教育 システムを構築することは不可能である。救急医が担当 する領域は極めて幅広い。内科や外科系とは全く異なる。 頭部から足先まで, 皮膚から内臓まで, 肉体的なものか 
ら精神的なものまで, 生から死まで, 個々の患者さんの 問題から医療体制そのものまで, そして, 救急医療から 災害医療までと幅広い。この新しい領域をひとつの大系 としてまとめていく緛皇みつけるという意味でこのシ リーズワークショップは大きな意義があった。

上田孝先生による「救急医学と救急医療のあるべき姿 - EBMから NBMへ」では, 救急医学と救急医療は表裏 一体であること, EBMから NBMの重要性を訴えるとと もに, ガイドラインの四角四面の世界でなく, 患者を総 合的に診ることが救急医として重要であることを訴えて いたという印象を受けた。貝沼関志先生による「外科系 集中治療室からみた救急医学, 救急医療と救急医」では, 藤田保健衛生大学病院SICUの経験をふまえて, 救急医, 集中治療医，各科専門医の連携を訴えながら，救急医は まさに総合医であることを強く訴えていたという印象を 受けた。田中裕先生による「救急医療における臨床倫 理学の確立を目指して」では, 救命医療を優先する我々 にとっては極めて重いが大切な命題, 臨床倫理学をテー マとしたものだけに大変重要なものであるという印象を 受けた。この難しい命題を取り上げ, 今後も追求してい こうとする姿勢に敬服したい。小泉健雄先生による「救
急医療の現場における終末期医療のあり方」では, 終末 期におけるDNARの問題などを論じたものである。我々 にとっては, 日常的に遭遇する生と死の問題であり, こ の点を新たなメスを入れようとした点で強い印象を受け た。池田栄人先生による「京都におけるDMAT ・災害拠 点病院合同研修会の試み」では災害医療の観点から救急 医学を見てみようとしたものである。災害医療と災害医 学は救急医療・救急医学の一部であり, 最も大切な部分 のひとつである。

ところで，これらの演者のプレゼンテーションのあと で, 我々は極めて幅広い領域の中にいることに改めて気 付いた。まるで大きな海の中にいるような気持ちとなっ た。海にいると海の特徵は分からない。特徵が分からな ければ大系化は難しい。海の特徵は液体が塩を含むこと である。では救急医学と救急医療の特徵は何だろう。私 は, 特徵は時間が限られていること, 限られた時間内で 適切な処置を行う教育とシステムの構築が不可欠である と考えている。私と同じく，この点を多くのワーク ショップ出席者が共有した点でこのワークショップは大 きな意義があった。難しい命題に取り組んでいただいた 各演者に感謝したい。 